\title{
Anatomy of the Brazilian middle class: identification, behaviours and expectations
}

\author{
Matthieu Clément, Yves-André Fauré, Jean-Philippe Berrou, \\ François Combarnous, Dominique Darbon and Éric Rougier
}

\begin{abstract}
This article aims to analyse the composition of the Brazilian middle class and its main behaviours and expectations. Combining a quantitative analysis based on the National Household Sample Survey (PNAD) and a qualitative survey carried out among households belonging to the middle class, it reveals the following characteristics. First, the Brazilian middle class is heterogeneous and a substantial part of it remains vulnerable to poverty. Second, the middle class exhibits consumer behaviour largely sustained by credit. Third, in terms of expectations, the Brazilian middle class prioritizes health, education, security and housing and is particularly critical of the quality of public services, all the more so as it faces a high tax burden. While the upper middle class is able to bypass these failures via private services, the most vulnerable elements of the middle class remain very dependent on these low-quality public services.
\end{abstract}

\section{Keywords}

Middle class, social structure, social classes, economic conditions, social conditions, social surveys, social statistics, Brazil

\section{JEL classification}

131, 054

\section{Authors}

Matthieu Clément is an associate professor at the Research Group on Theoretical and Applied Economics (GREThA), Bordeaux University, France.

Email: matthieu.clement@u-bordeaux.fr.

Yves-André Fauré is a researcher at the Research Cluster on Organization and Dissemination of Geographical Information (PRODIG), University of Paris 1 Panthéon-Sorbonne, France. Email: yafaure@yahoo.fr.

Jean-Philippe Berrou is an associate professor at the research unit "Les Afriques dans le Monde” (LAM), Sciences Po Bordeaux. Email: j.p.berrou@sciencespobordeaux.fr.

François Combarnous is a professor at GREThA, Bordeaux University, France.

Email: francois.combarnous@u-bordeaux.fr.

Dominique Darbon is a professor at LAM, Sciences Po Bordeaux.

Email: d.darbon@sciencespobordeaux.fr.

Éric Rougier is an associate professor at GREThA, Bordeaux University, France.

Email: eric.rougier@u-bordeaux.fr. 


\section{Introduction ${ }^{1}$}

Brazil has long been known for a polarized social structure with a very small elite, a mass of poor or very poor people and only a modest-sized intermediate class composed of senior administrative and commercial executives, engineers and senior technicians, often in the public sector or in private sector companies close to power. With recent social transformations, the country has seen a marked increase in the number and the proportion of individuals who have escaped poverty and joined the middle class. Indeed, the rise of the Brazilian middle class accelerated in the 2000s so that it now represents some $45 \%$ to $65 \%$ of the population, according to different estimates. This expansion has mainly resulted from economic growth, an increase in formal employment, the rise in real wages following the end of hyperinflation (subsequent to the 1994 Real Plan) and large-scale social programmes implemented in the 2000s, such as Bolsa Familia. It has also been sustained by the expansion of credit, especially during the years of Dilma Rousseff's presidency. However, Brazil is now suffering a severe economic crisis marked by a collapse in economic growth (-3.8\% in 2015 and 2016) whose main trigger has been the decline in demand for commodities from China, Brazil's main trading partner. This crisis has led to an upsurge in unemployment and poverty, as well as to an increase in the number of households that are overindebted, all of which could threaten the Brazilian middle class.

Experience from Western countries has shown that the emergence of middle classes contributes to the acceleration of economic development, particularly because of its effects on consumption (Banerjee and Duflo, 2008). From a social perspective, there is evidence that the development of the middle class breaks the dualism between a vast mass of poor and a small elite, thus helping to strengthen social cohesion and political stability. The new requirements expressed by the middle class can also help to promote democratization (Easterly, 2001).

From an academic point of view, the idea of the "middle class" is a transdisciplinary one whose use and definition remain highly controversial. Broadly speaking, four approaches can be identified: (i) an income-based economic approach, (ii) a sociological approach (based on education, occupation and social status more generally), (iii) a subjective approach (based on class consciousness) and (iv) a managerial approach (based on consumption habits). This great diversity of approaches means that the use of the term "middle class" is sometimes confusing.

The Brazilian authorities have made much of the topic, seeing in it a simple and effective means of demonstrating the legitimacy and efficacy of the policies they have adopted over the last 10 years. From an international viewpoint, it is also a way of proving that Brazil is a full member of the club of emerging countries and, as such, in a position to demand the establishment of a new order in international relations. The sensitivity of these issues explains why the federal government has increased the volume of rhetoric both in Brazil and in the international arena, boasting of this Brazilian success, as former President Dilma Rousseff did at the World Economic Forum in Davos in January 2014.

It was in this quite euphoric atmosphere that the government created, in July 2008, a ministerial-level Secretariat of Strategic Affairs. The Secretariat was made responsible for helping the government to formulate long-term public policies and has subsequently focused more particularly on defining the Brazilian middle class and monitoring actions to consolidate this social group. The Secretariat bases its measure of the middle class on gross monthly income per capita and links it to the notion of vulnerability, i.e. the probability of the identified classes remaining poor or returning to poverty. The class $C$ thus identified (on a spectrum of five classes from $A$ to $E$ ) has been shown to consist now of nearly 54\% of the Brazilian population and to have a purchasing power of a trillion reais (SAE, 2012a). For the authorities, the preponderance of this category represents the face of a new Brazil and is proud

\footnotetext{
1 This study derives from a comparative research project funded by the French Development Agency (AFD) and analysing "the implications of the rise of the middle classes in developing and emerging countries". The project covered four different countries: Brazil, Côte d'Ivoire, Turkey and Viet Nam.
} 
evidence of progress that demonstrates the effectiveness of the social policies implemented since 2003 and the presidency of Lula da Silva. The Social Policy Centre of the Getúlio Vargas Foundation and its founder Marcelo Neri also had a pioneering role in the study of the "new middle class" (Neri, 2012; Neri and De Melo, 2008), as did the Brazilian Institute of Geography and Statistics (IBGE) and the Brazilian Association of Research Companies (ABEP). For IBGE, the middle class, defined as individuals belonging to households whose per capita income is between half and five times the minimum wage, represented $63 \%$ of the population in 2014. Finally, comparative studies applied to Latin American countries have also highlighted the rise of middle-income categories on the continent in general and in Brazil in particular (Franco, Hopenhayn and León, 2011; Ferreira and others, 2013).

Despite the enthusiasm of this literature, more critical studies stress the vulnerability of the supposed "new middle class" (Xavier Sobrinho, 2011; Pochmann, 2012; Scalon and Salata, 2012). Pochmann (2012) explains that 94\% of jobs created between 2004 and 2010 paid no more than 1.5 times the minimum wage. In addition to still being low-paid, most of these new jobs, the bulk of them in the service sector, are very low-skilled, have very poor conditions of employment and are subject to high levels of instability. In other words, households recently lifted out of poverty as a result of real wage increases and social policies aimed at helping the poor will not have the characteristics of socioeconomic stability traditionally associated with membership of the middle class. The economic crisis currently faced by Brazil is obviously likely to increase the vulnerability of a large part of the population.

The rise of the middle class is an important and topical issue in today's Brazil and is of great interest to policymakers. This article, which contains three sections after the present introduction, aims to analyse the composition of this intermediate category and its behaviours and aspirations. It has two main objectives: (i) to propose a method for identifying the Brazilian middle class that highlights its heterogeneity and (ii) to analyse the behaviours and aspirations of this middle class. Methodologically, we adopt a two-step empirical approach. First, section II carries out a quantitative analysis based on data from the National Household Sample Survey (PNAD) to identify and characterize the Brazilian middle class. The second step, in section III, is to use a qualitative survey conducted among middle-class households from two contrasting regions, the Rio de Janeiro and Fortaleza metropolitan areas, to understand the dynamics of this group, but also to highlight its main aspirations in terms of public policies. Section IV presents the conclusion.

\section{Identification and characterization of the Brazilian middle class}

\section{Method and data}

The purpose of the quantitative analysis is to identify the Brazilian middle class, reveal its potential heterogeneity and describe its main socioeconomic characteristics. To do this, we rely on household survey data and adopt a sequential method that broadly follows the approach proposed by Bonnefond, Clément and Combarnous (2015). This approach is multidimensional and combines an economic definition of the middle class (based on income) and a sociological definition (based on employment and education). The idea in this first step is to delimit a middle-income group. The main issue is not to identify precisely the number or percentage of people in the middle class (given the lack of consensus on the choice of income range) but rather to delimit a group of individuals located in the middle of the income distribution. In the second step, the approach consists in mobilizing more qualitative information on employment and education to identify the different components of the middle-income class identified in the previous step and thence highlight the potential heterogeneity of this intermediate group. 


\section{(a) First step: identification of the middle-income class}

The aim in this step is to test and compare most of the intervals used in the economic literature to identify the middle-income class. In the literature, the statistical identification of the middle class relies primarily on an income-based definition whereby households falling within a specific income range are considered to belong to the middle-income class. Three broad approaches should be distinguished.

First, the relative approach defines the middle class as the population located in the middle of the income distribution. Relative intervals are most often constructed from median income or average income: between $75 \%$ and $125 \%$ of median income (Birdsall, Graham and Pettinato, 2000), between $50 \%$ and $150 \%$ of median income (Castellani and Parent, 2011) or between $100 \%$ and $250 \%$ of average income (Song and others, 2016). In Brazil, IBGE also adopts a relative approach, using a range from 0.5 to 5 times the official minimum wage. Second, the absolute approach is primarily used for international comparisons. It is based on intervals expressed in purchasing power parity (PPP) dollars. Many intervals are constructed with a lower bound of US\$ 2 per capita per day (in PPP). The underlying idea is that the middle class starts where poverty ends. The following intervals can be found in the literature: US\$ 2 to US\$10 (Barnerjee and Duflo, 2008), US\$2 to US\$ 13 (Ravallion, 2010) and US\$ 2 to US\$ 20 (AsDB, 2010; Castellani and Parent, 2011). However, as the Asian Development Bank (AsDB, 2010) acknowledges, households with per capita incomes just above US\$2 remain highly vulnerable to a return to poverty in the case of socioeconomic shocks. This has led other authors to use a lower limit of US\$ 10. Ranges often used now are US\$10 to US\$20 (Milanovic and Yitzhaki, 2002), US\$ 10 to US\$ 50 (Ferreira and others, 2013) and US\$10 to US\$100 (Kharas, 2010). Third, the mixed approach consists in combining an absolute lower bound and a relative upper bound. The interval proposed by Birdsall (2010) has a lower limit of US\$10 and an upper limit corresponding to the ninety-fifth percentile of the income distribution. Overall, the objective of this first step is to compare different income intervals and select one for its ability to accurately trace the development of social stratification in Brazil.

\section{(b) Second step: cluster analysis and characterization of the middle class}

To explore the heterogeneity of the middle-income class identified in the previous step from a multidimensional point of view, we applied a mixed classification procedure to several variables describing the occupational and educational status of households in this group. Specifically, we selected four categorical variables related to the education and employment characteristics of the household head: (i) education (highest level attained), (ii) occupation, (iii) employment status and (iv) institutional sector.

Setting out from these four variables, the statistical procedure classified a large set of individuals characterized by their first factorial coordinates, themselves generated by an initial factor analysis procedure (in this case, a multiple correspondence analysis of the four variables). A first classification was obtained by cross-referencing several basic partitions built around moving means, after which the stable classes thus formed were aggregated by a hierarchical classification method. We chose to use the Ward aggregation criterion. The partition used (the number of groups retained within the middle-income class) was selected by analysing the aggregation node values and the dendrogram (the diagram that synthesizes the successive aggregation stages). This process yielded a classification into homogeneously composed, clearly distinct groups. Lastly, the better to characterize these groups, we compared the distributions of the different classification variables mentioned above and refined the analysis by comparing the distribution or average values of a set of additional variables, called characterization variables.

The quantitative analysis was based on the PNAD survey conducted by IBGE. The baseline survey was carried out in 2014 and covered approximately 115,000 households. PNAD data for the years 2001, 2004, 2007 and 2011 were also used to determine the change in the percentage of the population represented by the middle-income class over time. 


\section{The size of the middle-income class}

Income is defined as monthly per capita household income, going by PNAD data. The various income intervals selected produced very disparate results. For the year 2014 (see table 1), the proportion of the population represented by the middle-income class ranged from $20 \%$ to $73 \%$, depending on the criterion. The changes identified are also very heterogeneous (see table 2). The first two criteria (US\$2 to US\$ 10 and US\$ 2 to US\$20) yield a decrease in the size of the middle class in Brazil, while all the others show a more or less marked increase. This is explained by the variety of intervals, with many overlapping only very partially, if at all. For instance, the US\$2 to US\$10 interval does not intersect any of the intervals starting at US\$10. This great disparity obviously raises the problem of the choice of the most relevant criterion.

Table 1

Comparison of different criteria for defining the middle-income class, 2014

\begin{tabular}{|c|c|c|c|c|c|}
\hline \multirow[b]{2}{*}{ Criterion } & \multicolumn{2}{|c|}{ Income range } & Poor & Middle-class & Rich \\
\hline & $\begin{array}{l}\text { Monthly per capita reais } \\
\text { (2014 prices) }\end{array}$ & $\begin{array}{l}\text { Monthly per capita dollars } \\
\text { (2011 PPP, } 2014 \text { prices) }^{\text {a }}\end{array}$ & \multicolumn{3}{|c|}{ (percentages of the population) } \\
\hline [US\$ 2 to US\$ 10] & [R\$ 104.4 to $R \$ 522]$ & [US\$ 60 to US\$ 300] & 3.1 & 30.5 & 66.4 \\
\hline [US\$ 2 to US\$ 20] & [R\$ 104.4 to $R \$ 1,044]$ & [US\$ 60 to US\$ 600] & 3.1 & 63.9 & 33.0 \\
\hline [US\$ 4 to US\$ 20] & {$[R \$ 208.8$ to $R \$ 1,044]$} & [US\$ 120 to US\$ 600] & 8.4 & 58.6 & 33.0 \\
\hline [US\$ 10 to US\$ 20] & {$[R \$ 522$ to $R \$ 1,044]$} & [US\$ 300 to US\$ 600] & 33.6 & 33.4 & 33.0 \\
\hline [US\$ 10 to US\$50] & {$[R \$ 522$ to $R \$ 2,610]$} & [US\$ 300 to US\$ 1,500$]$ & 33.6 & 57.4 & 9.0 \\
\hline [US\$ 10 to US\$100] & {$[R \$ 522$ to $R \$ 5,220]$} & [US\$ 300 to US\$ 3,000] & 33.6 & 63.4 & 3.0 \\
\hline [ $75 \%$ to $125 \%$ of median income] & [R\$ 543 to $R \$ 905]$ & [US\$ 312 to US\$ 520] & 34.9 & 26.1 & 39.0 \\
\hline [50\% to $150 \%$ of median income] & {$[R \$ 362$ to $R \$ 1,086]$} & [US\$ 208 to US\$ 624] & 19.4 & 48.8 & 31.8 \\
\hline [100\% to $250 \%$ of mean income] & {$[R \$ 1,226$ to $R \$ 3,065]$} & [US\$ 705 to US\$ 1,762 ] & 73.0 & 20.0 & 7.0 \\
\hline [US\$ 10 to percentile 90] & {$[R \$ 522$ to $R \$ 2,471]$} & [US\$ 300 to US\$1,420] & 33.6 & 56.4 & 10.0 \\
\hline [US\$ 10 to percentile 95] & {$[R \$ 522$ to $R \$ 3,875]$} & [US\$ 300 to US\$ 2,227$]$ & 33.6 & 61.4 & 5.0 \\
\hline [0.5 to 5 times minimum wage] & {$[R \$ 362$ to $R \$ 3,620]$} & [US\$ 208 to US\$ 2,080] & 21.4 & 73.1 & 5.5 \\
\hline
\end{tabular}

Source: National Household Sample Survey (PNAD), 2014.

a The purchasing power parity (PPP) conversion coefficient used (2011 PPP adjusted to 2014 prices) is 1.74, as calculated by the World Bank.

Table 2

Evolution of the size of the middle income-class on different criteria, 2001-2014 (Percentages of the population)

\begin{tabular}{llllll}
\hline Income range & 2001 & 2004 & 2007 & 2011 & 2014 \\
\hline [US\$ 2 to US\$10] & 50.3 & 51.8 & 42.6 & 35.7 & 30.5 \\
\hline [US\$ 2 to US\$ 20] & 70.4 & 73.0 & 71.1 & 67.8 & 63.9 \\
\hline [US\$ 4 to US\$ 20] & 54.1 & 57.9 & 59.4 & 60.4 & 58.6 \\
\hline [US\$ 10 to US\$ 20] & 20.1 & 21.2 & 28.5 & 32.1 & 33.4 \\
\hline [US\$ 10 to US\$ 50] & 33.1 & 34.4 & 44.5 & 51.9 & 57.4 \\
\hline [US\$ 10 to US\$ 100] & 37.0 & 38.2 & 48.9 & 57.0 & 63.4 \\
\hline [75\% to 125\% of median income] & 15.8 & 16.7 & 23.2 & 25.1 & 26.1 \\
\hline [50\% to 150\% of median income] & 36.5 & 38.7 & 43.0 & 46.3 & 48.8 \\
\hline [100\% to 250\% of mean income] & 11.1 & 11.1 & 13.3 & 16.4 & 20.0 \\
\hline [US\$ 10 to percentile 90] & 32.8 & 33.9 & 43.9 & 51.4 & 56.4 \\
\hline [US\$ 10 to percentile 95] & 35.8 & 36.9 & 47.6 & 55.3 & 61.4 \\
\hline [0.5 to 5 times minimum wage] & 51.2 & 53.3 & 61.0 & 68.0 & 73.1 \\
\hline
\end{tabular}

Source: National Household Sample Survey (PNAD), 2001, 2004, 2007, 2011 and 2014.

Note: Incomes for 2001, 2004, 2007 and 2011 have been converted to 2014 prices using the extended national consumer price index (IPCA). The purchasing power parity (PPP) conversion coefficient used (2011 PPP adjusted to 2014 prices) is 1.74 , as calculated by the World Bank. 
It seems imperative to select a lower bound that is neither too low (to avoid the risk of capturing households that are poor rather than middle-class) nor too high (to ensure that non-poor households which remain potentially vulnerable to a return to poverty are included). Accordingly, we follow Birdsall (2010) and Ferreira and others (2013) in using a lower limit of US\$ 10 per day. It is interesting to note that this US\$ 10 threshold represents approximately $70 \%$ of the Brazilian minimum wage, slightly above the $50 \%$ of the minimum wage that is the lower limit used by IBGE to identify the middle class. It can be assumed that this relatively low threshold makes it possible to capture households that are relatively vulnerable to a risk of returning to poverty. The upper bound is set at the ninety-fifth percentile of the income distribution (P95), in line with Birdsall (2010), who considers this relative limit to exclude "that portion of the population within a country whose income is most likely to be from inherited wealth or based on prior or current economic rents (...) and thus less associated with productive and primarily labour-based activity than for the non-rich" (Birdsall, 2010, p. 7). In a nutshell, our identification of the middle-income class in Brazil is based on an interval ranging from US\$10 per day to the ninety-fifth percentile of the distribution, i.e. from 522 reais to 3,875 reais per month at 2014 prices.

With the interval [US\$ 10; P95], the middle-income class represents $61.4 \%$ of the Brazilian population, a level close to previous estimates (mainly falling into the $45 \%$ to $65 \%$ bracket). The expansion of this middle-income group since the beginning of the 2000 s is also confirmed, insofar as it represented only 35.8\% of Brazilian households in 2001.

We then set out to characterize the three groups identified on the basis of this income criterion ("poor", "middle-class" and "rich") using the different classification variables selected (see table 3). Broadly speaking, table 3 shows that for most education and employment characteristics, heads of households belonging to the middle class occupy an intermediate position between "poor" and "rich". However, it can be seen that the proportions of household heads with secondary education, working as manual workers and working in the formal private sector are highest for the middle class. All this suggests that there are strong markers of membership of Brazil's middle class and that this middle class is probably heterogeneous in terms of socioeconomic characteristics.

Table 3

Characteristics (classification variables) of poor, middle-class and rich household heads, 2014 (Percentages)

\begin{tabular}{lrrrr}
\hline & Poor & Middle-class ${ }^{\text {a }}$ & Rich & Total \\
\hline Education & & & & \\
\hline No education & 12.4 & 7.7 & 0.2 & 8.9 \\
\hline Primary education & 58.0 & 44.7 & 8.6 & 47.4 \\
\hline Secondary education & 26.3 & 31.1 & 16.9 & 28.7 \\
\hline Tertiary education & 3.3 & 16.6 & 74.4 & 15.0 \\
\hline Occupation & & & & 31.0 \\
\hline No job (retiree, inactive, unemployed) & 34.2 & 30.0 & 21.8 & 10.0 \\
\hline Managers, executives & 2.0 & 11.0 & 51.5 & 5.4 \\
\hline Intermediate occupations & 2.1 & 6.7 & 11.9 & 24.1 \\
\hline Service workers & 25.4 & 24.7 & 8.3 & 18.9 \\
\hline Workers & 19.0 & 20.1 & 3.8 & 10.6 \\
\hline Farmers & 17.3 & 7.5 & 2.8 & \\
\hline Employment status & & & & 31.0 \\
\hline No job (retiree, inactive, unemployed) & 34.2 & 30.0 & 21.8 & 43.8 \\
\hline Paid employees & 40.0 & 45.6 & 46.7 & 18.8 \\
\hline Self-employed without employees & 20.5 & 18.2 & 15.3 & 3.4 \\
\hline Self-employed with employees & 0.6 & 3.9 & 15.5 & 3.0 \\
\hline Unpaid workers & 4.7 & 2.3 & 0.7 & \\
\hline
\end{tabular}


Table 3 (concluded)

\begin{tabular}{|c|c|c|c|c|}
\hline & Poor & Middle-class $^{\mathrm{a}}$ & Rich & Total \\
\hline \multicolumn{5}{|l|}{ Institutional sector } \\
\hline No job (retiree, inactive, unemployed) & 34.2 & 30.0 & 21.8 & 31.0 \\
\hline Private formal & 46.4 & 52.3 & 49.1 & 50.2 \\
\hline Private informal & 15.3 & 7.7 & 3.3 & 10.0 \\
\hline Public & 4.1 & 10.0 & 25.8 & 8.8 \\
\hline
\end{tabular}

Source: National Household Sample Survey (PNAD), 2014.

a The middle class is defined as households whose per capita daily income ranges from US\$10 to the ninety-fifth percentile of income distribution.

\section{The heterogeneity of the Brazilian middle class}

In the second step, we isolate households belonging to the middle-income class and analyse the heterogeneity of the group by carrying out the multidimensional cluster analysis described above. The results of this classification lead us to identify seven distinct groups within the Brazilian middle-income class. Going by the analysis of the comparative distributions of the classification variables and a set of characterization variables (see tables 4 and 5 , respectively), we can describe these seven groups.

Table 4

Characteristics (classification variables) of clusters derived from the mixed classification procedure, 2014

(Percentages)

\begin{tabular}{|c|c|c|c|c|c|c|c|c|}
\hline & Group 1 & Group 2 & Group 3 & Group 4 & Group 5 & Group 6 & Group 7 & Total \\
\hline & $(30)$ & (7) & (10) & (2) & (24) & (20) & (7) & \\
\hline Education & & & & & & & & \\
\hline No education & 16.2 & 0.0 & 0.3 & 29.7 & 4.7 & 2.5 & 7.4 & 7.7 \\
\hline Primary education & 55.8 & 5.0 & 9.7 & 58.8 & 58.6 & 38.3 & 59.4 & 44.7 \\
\hline Secondary education & 18.6 & 60.4 & 18.1 & 8.3 & 33.2 & 48.6 & 28.9 & 31.1 \\
\hline Tertiary education & 9.4 & 34.6 & 72.0 & 3.2 & 3.6 & 10.7 & 4.3 & 16.6 \\
\hline Occupation & & & & & & & & \\
\hline No job (retiree, inactive, unemployed) & 100.0 & 0.0 & 0.0 & 0.0 & 0.0 & 0.0 & 0.0 & 30.0 \\
\hline Managers, executives & 0.0 & 0.0 & 89.1 & 2.5 & 2.8 & 0.0 & 3.6 & 11.0 \\
\hline Intermediate occupations & 0.0 & 94.9 & 0.4 & 0.6 & 1.0 & 0.0 & 0.8 & 6.7 \\
\hline Service workers & 0.0 & 0.0 & 9.6 & 6.1 & 0.0 & 100.0 & 54.3 & 24.7 \\
\hline Workers & 0.0 & 5.0 & 0.4 & 5.4 & 76.5 & 0.0 & 28.5 & 20.1 \\
\hline Farmers & 0.0 & 0.1 & 0.5 & 85.4 & 19.8 & 0.0 & 12.9 & 7.5 \\
\hline Employment status & & & & & & & & \\
\hline No job (retiree, inactive, unemployed) & 100.0 & 0.0 & 0.0 & 0.0 & 0.0 & 0.0 & 0.0 & 30.0 \\
\hline Paid employees & 0.0 & 85.0 & 69.0 & 0.0 & 47.9 & 71.8 & 100.0 & 45.6 \\
\hline Self-employed without employees & 0.0 & 14.2 & 6.4 & 0.0 & 48.1 & 27.7 & 0.0 & 18.2 \\
\hline Self-employed with employees & 0.0 & 0.8 & 24.6 & 0.0 & 4.1 & 0.5 & 0.0 & 3.9 \\
\hline Unpaid workers & 0.0 & 0.0 & 0.0 & 100.0 & 0.0 & 0.0 & 0.0 & 2.3 \\
\hline Institutional sector & & & & & & & & \\
\hline No job (retiree, inactive, unemployed) & 100.0 & 0.0 & 0.0 & 0.0 & 0.0 & 0.0 & 0.0 & 30.0 \\
\hline Private formal & 0.0 & 49.5 & 58.8 & 100.0 & 98.4 & 88.4 & 0.0 & 52.3 \\
\hline Private informal & 0.0 & 4.9 & 3.0 & 0.0 & 0.0 & 0.0 & 100.0 & 7.7 \\
\hline Public & 0.0 & 45.6 & 38.2 & 0.0 & 1.6 & 11.6 & 0.0 & 10.0 \\
\hline
\end{tabular}

Source: National Household Sample Survey (PNAD) 2014.

Note: The shaded cells identify the modalities that are statistically (at $5 \%$ level) more heavily represented in the group considered than in the rest of the middle class. 
Table 5

Characteristics (characterization variables) of clusters derived from the mixed classification procedure, 2014

(Percentages)

\begin{tabular}{|c|c|c|c|c|c|c|c|c|}
\hline & \multirow{2}{*}{$\begin{array}{c}\text { Group } 1 \\
(30)\end{array}$} & \multirow{2}{*}{$\begin{array}{c}\text { Group } 2 \\
(7)\end{array}$} & \multirow{2}{*}{$\begin{array}{c}\text { Group } 3 \\
(10)\end{array}$} & \multirow{2}{*}{$\begin{array}{c}\text { Group } 4 \\
\text { (2) }\end{array}$} & \multirow{2}{*}{$\begin{array}{c}\text { Group } 5 \\
(24)\end{array}$} & \multirow{2}{*}{$\begin{array}{c}\text { Group } 6 \\
(20)\end{array}$} & \multirow{2}{*}{$\begin{array}{c}\text { Group } 7 \\
(7)\end{array}$} & \multirow{2}{*}{ Total } \\
\hline & & & & & & & & \\
\hline \multicolumn{9}{|l|}{ Area of residence } \\
\hline Urban & 91.6 & 97.4 & 96.1 & 49.4 & 82.1 & 96.3 & 87.6 & 90.0 \\
\hline Rural & 8.4 & 2.6 & 3.9 & 50.6 & 17.9 & 3.7 & 12.4 & 10.0 \\
\hline \multicolumn{9}{|l|}{ Region } \\
\hline North & 9.7 & 13.3 & 13.6 & 10.5 & 11.8 & 12.1 & 12.9 & 11.6 \\
\hline North-east & 24.4 & 21.9 & 20.8 & 33.0 & 17.9 & 21.2 & 21.6 & 21.7 \\
\hline South-east & 36.2 & 34.2 & 31.7 & 20.5 & 34.3 & 34.6 & 32.7 & 34.2 \\
\hline South & 19.8 & 19.1 & 20.8 & 28.2 & 22.7 & 19.0 & 17.5 & 20.4 \\
\hline West-central & 9.9 & 11.4 & 13.1 & 7.9 & 13.4 & 13.1 & 15.2 & 12.1 \\
\hline \multicolumn{9}{|l|}{ Gender } \\
\hline Female & 58.2 & 27.8 & 37.5 & 40.2 & 9.3 & 45.6 & 43.7 & 38.6 \\
\hline Male & 41.8 & 72.2 & 62.5 & 59.8 & 90.7 & 54.4 & 56.3 & 61.4 \\
\hline \multicolumn{9}{|l|}{ Skin colour } \\
\hline White & 59.3 & 60.0 & 65.6 & 55.0 & 54.2 & 55.3 & 52.0 & 57.5 \\
\hline Black & 39.8 & 39.1 & 33.3 & 44.3 & 45.1 & 44.0 & 47.2 & 41.7 \\
\hline Yellow & 0.5 & 0.5 & 1.0 & 0.4 & 0.4 & 0.3 & 0.3 & 0.5 \\
\hline Brown & 0.0 & 0.0 & 0.0 & 0.0 & 0.0 & 0.0 & 0.0 & 0.0 \\
\hline Indigenous & 0.4 & 0.4 & 0.1 & 0.3 & 0.4 & 0.3 & 0.5 & 0.3 \\
\hline \multicolumn{9}{|l|}{ Retired } \\
\hline Yes & 63.4 & 3.2 & 5.0 & 77.8 & 11.6 & 5.8 & 12.2 & 26.3 \\
\hline No & 36.6 & 96.8 & 95.0 & 22.2 & 88.4 & 94.2 & 87.8 & 73.7 \\
\hline \multicolumn{9}{|l|}{ Multi-activity } \\
\hline Yes & 0.0 & 6.3 & 8.5 & 0.4 & 3.0 & 4.1 & 3.6 & 3.2 \\
\hline No & 100.0 & 93.7 & 91.5 & 99.6 & 97.0 & 95.9 & 96.4 & 96.8 \\
\hline \multicolumn{9}{|l|}{ Housing } \\
\hline House & 88.4 & 78.3 & 74.5 & 97.9 & 93.6 & 86.7 & 91.1 & 87.4 \\
\hline Apartment & 11.3 & 21.6 & 25.4 & 2.0 & 6.1 & 12.9 & 8.2 & 12.3 \\
\hline Other & 0.2 & 0.1 & 0.1 & 0.1 & 0.3 & 0.4 & 0.7 & 0.3 \\
\hline \multicolumn{9}{|l|}{ Equipment goods } \\
\hline Freezer & 17.4 & 17.1 & 22.0 & 30.3 & 21.1 & 15.7 & 12.9 & 18.4 \\
\hline Washing machine & 61.7 & 78.4 & 82.9 & 37.5 & 60.9 & 66.8 & 51.3 & 64.7 \\
\hline Computer & 39.2 & 82.2 & 87.8 & 22.0 & 51.6 & 59.1 & 38.8 & 53.8 \\
\hline Motorized vehicle & 44.7 & 75.8 & 83.4 & 51.2 & 71.1 & 58.0 & 48.0 & 60.2 \\
\hline \multicolumn{9}{|l|}{ Mean of quantitative variables } \\
\hline Household size & 2.423 & 2.898 & 3.033 & 2.298 & 2.884 & 2.769 & 2.556 & 2.704 \\
\hline Number of rooms & 5.947 & 6.110 & 6.815 & 6.246 & 5.702 & 5.532 & 5.196 & 5.872 \\
\hline Age of household head & 64.679 & 41.396 & 42.859 & 65.616 & 46.049 & 43.298 & 45.161 & 50.817 \\
\hline Household participation rate & 0.222 & 0.686 & 0.674 & 0.837 & 0.735 & 0.760 & 0.797 & 0.583 \\
\hline School enrolment in public sector & 0.580 & 0.455 & 0.388 & 0.716 & 0.715 & 0.648 & 0.741 & 0.596 \\
\hline Monthly per capita household income & 1141 & 1535 & 1839 & 1010 & 1143 & 1125 & 1017 & 1232 \\
\hline
\end{tabular}

Source: National Household Sample Survey (PNAD), 2014.

Note: The shaded cells identify the modalities that are statistically (at $5 \%$ level) more heavily represented in the group considered than in the rest of the middle class. The bold cells identify the modalities that are statistically (at $5 \%$ level) less heavily represented in the group considered than in the rest of the middle class. For quantitative variables, shaded and bold cells identify respectively the means that are significantly higher and lower than the mean for the whole middle class. 


\section{Group 1: Retired and inactive middle class (30\% of the middle-income class)}

This first group mainly includes households headed by retired individuals, who are also less well educated than household heads in other middle-class groups. These households are slightly overrepresented in the north-east region and underrepresented in the north and west-central regions. They are smaller than other groups' and more often headed by women. Their incomes and level of durable goods equipment are quite low compared to the rest of the middle class.

\section{Group 2: Intermediate occupations and public sector middle class (7\%)}

This group is overwhelmingly made up of employees in intermediate occupations, particularly in the public sector, whose level of education is relatively high overall. These households are almost all urban, more likely than others to live in apartments, rarely headed by a woman and more often than not multi-active. They are quite large households whose heads are very young and whose incomes are high compared to those of other middle-class households. They are significantly better equipped with durable goods (washing machine, computer or motor vehicle) and are more likely to enrol their children in private schools.

\section{Group 3: Employer, managerial and executive middle class (10\%)}

Household heads in this group are mainly managers, employers and senior executives from the formal private and public sectors whose level of education is very high overall. Almost entirely urban, many of these households live in apartments and more often than not they are multi-active. Whites are overrepresented in this group and blacks underrepresented. The households considered are large and their heads rather young. Their incomes are the highest among the different middle-class groups. This is also the group with the highest level of durable goods equipment and that which most frequently sends its children to private schools.

\section{Group 4: Active retired middle class (2\%)}

This subset of the middle class is of limited size and composed of very specific households. These are mainly households headed by retired individuals who remain active and do unpaid work, most of them in agriculture. We can legitimately think here of small-scale subsistence agriculture carried out to compensate for small pensions. They are poorly educated and overrepresented in the north-east region (the poorest) and rare in the south-east region (the richest) and almost all live in houses. Their incomes are on average among the lowest in the middle class, despite an extremely high labour market participation rate. They are also less well equipped with durable goods than the rest of the middle class.

\section{Group 5: Worker and farmer middle class (24\%)}

This group includes employees and a very high proportion of the self-employed. It consists of a large majority of workers and most farmers, all of them working in the formal private sector. Their average level of education is quite low. This class is relatively underrepresented in the north-east region and is overwhelmingly male. Households in this group are quite small and their per capita incomes quite low for the middle class. In terms of ownership of durable goods, they occupy an intermediate position, being better equipped than average for certain goods (freezers and motor vehicles) but less well for other goods (washing machines and computers). 


\section{Group 6: Service worker middle class (20\%)}

Household heads in this group are mainly employees and self-employed with a relatively high level of education. They work quasi-exclusively in the formal private service sector, they are urban and women are overrepresented by comparison with other subsets of the middle class. The mean income of this group is rather low despite a relatively high labour market participation rate. These households have an intermediate level of durable goods equipment, with relatively high rates of washing machine and computer ownership but low rates of freezer and motor vehicle ownership.

\section{Group 7: Informal employee middle class (7\%)}

The last group is made up entirely of wage-earning household heads working in the informal private sector. Whether they are employed in the service sector or as workers or even farmers, they are clearly less well educated than other subsets of the middle class. Households in this group have the smallest dwellings and very low incomes, despite a very high labour market participation rate. This group also has one of the lowest durable goods equipment levels.

\section{The vulnerability of the Brazilian middle class}

The cluster analysis highlights the great heterogeneity of the Brazilian middle class and indicates a form of bipolarization, with a rather affluent and urban middle class in stable, high-skilled jobs coexisting with a more fragile, less well-educated and lower-income middle class whose jobs are less stable, of lower quality (informal, agriculture) or both.

Indeed, groups 2 and 3 have significantly higher education levels and average incomes than the rest of the Brazilian middle class. They could therefore be seen as constituting the upper middle class, accounting for a limited proportion (17\%) of the whole middle class in Brazil. These groups include most civil servants, often perceived as Brazil's historical middle class, although they also contain private sector employees and self-employed individuals. The two groups also stand out clearly from the rest of the middle class in terms of durable goods equipment levels and their greater propensity to enrol their children in private schools. These are strong markers for membership of the upper middle class in Brazil, thus emphasizing the role of consumption-related behaviour in social differentiation.

The other five groups (83\% of the middle class) have lower and fairly similar average incomes. The percentage of vulnerable households is difficult to estimate, however. It is important to note that some households belong to groups with a relatively stable occupational status: formal workers in the primary and secondary sectors (24\%) and formal tertiary sector workers (20\%). If we consider that the stability of their jobs moves them away from the vulnerable zone, the proportion of genuinely vulnerable households in the middle class can be put at 39\%. Whatever the percentage chosen, there is no doubt that the proportion of vulnerable households in the Brazilian middle class is high. Some of the literature points this out, suggesting that such households are difficult to equate with the middle classes in the Western sense of the concept and that they belong rather to the working class (Xavier Sobrinho, 2011; Pochmann, 2012; Scalon and Salata, 2012).

Birdsall, Lustig and Meyer (2014), working in the Latin American context, call individuals making up this vulnerable class "strugglers". According to these authors, two phenomena heighten the vulnerability of this group. First, within the redistributive system, strugglers are "net payers" like the upper middle class and the wealthy class and unlike the poorest. They benefit much less from public transfer programmes than the poorest and, at the same time, are subject to high indirect taxation. In addition, lacking the income level of the upper middle class and the rich class, strugglers are more dependent on low-quality public services, especially in the fields of education and health, which could restrict their prospects of upward mobility. 


\section{Trajectories, behaviours and aspirations of the Brazilian middle class: lessons from a qualitative household survey}

To complete the characterization of the Brazilian middle class, a qualitative survey was carried out among households judged to be characteristic of the different groups identified during the quantitative analysis. The main objective of this qualitative survey was to examine intergenerational changes in the living conditions of the Brazilian middle classes and to identify their behaviours and aspirations and the expectations they had of the public authorities.

\section{Survey methodology}

The quantitative analysis applied to the PNAD data identified seven distinct groups within Brazil's middle class. This structure served as a sampling basis for the qualitative survey. Given its small size ( $2 \%$ of the middle-income class), group 4, composed of the "active retired", was merged with group 1, "retired and inactive". A total of 30 interviews were conducted with household heads from these different groups in two contrasting regions of Brazil: the Rio de Janeiro metropolitan area (Rio de Janeiro State, south-east region) and the Fortaleza metropolitan area (Ceará State, north-east region). The former has much more favourable socioeconomic indicators than the latter. In addition, we took care to distribute the interviews between urban and rural areas in a way that reflected the high rate of urbanization in Brazil (around 86\%).

Table 6 shows the distribution of interviews based on the relative size of each group in the Brazilian middle class. The qualitative survey was conducted in April and May 2017. The interview grid included about 100 questions (closed and open). ${ }^{2}$ Because of the limited sample size, it was not possible to arrive at robust results at the group scale. However, the qualitative survey yields interesting results about the intergenerational mobility, priorities and aspirations of the Brazilian middle class as a whole that complement those derived from the quantitative analysis.

Table 6

Sampling scheme

\begin{tabular}{lccccr}
\hline Group & $\begin{array}{c}\text { Share } \\
\text { (percentages) }\end{array}$ & $\begin{array}{c}\text { Theoretical number } \\
\text { of interviews } \\
\text { (out of 30) }\end{array}$ & $\begin{array}{c}\text { Number of } \\
\text { interviews } \\
\text { conducted }\end{array}$ & Rio de Janeiro & Fortaleza \\
\hline 1. Retirees and inactive & 32 & 9.6 & 9 & 3 & 6 \\
\hline 2. Intermediate occupations and civil servants & 7 & 2.1 & 3 & 1 & 2 \\
\hline 3. Employers, managers and executives & 10 & 3.0 & 3 & 1 & 2 \\
\hline 5. Workers and farmers & 24 & 7.2 & 7 & 4 & 3 \\
\hline 6. Service workers & 20 & 6.0 & 6 & 3 & 3 \\
\hline 7. Informal employees & 7 & 2.1 & 2 & 1 & 1 \\
\hline Total & 100 & 30 & 30 & 13 & 17 \\
\hline
\end{tabular}

Source: Prepared by the authors.

The qualitative survey made it possible to estimate the incomes of the households surveyed. The average monthly per capita income of the households in the sample was 2,433 reais. It should be noted that these incomes are expressed at 2017 current prices and are therefore not directly comparable to incomes from the quantitative analysis (2014 prices).

\footnotetext{
2 The questionnaires in Fortaleza and Rio de Janeiro were administered, respectively, in collaboration with Janaina Araújo, who holds a master's degree in economics from the Federal University of Ceará, and Caroline Miranda, a master's student in economics at the Institute of Economics of the Federal University of Rio de Janeiro.
} 
A methodological requirement in the administration of the questionnaires was never to use the term "class" or "social class" in order not to influence respondents' answers. However, in Brazil, these expressions have been part of everyday language since the mid-2000s. In particular, the term "middle class" has gone from being an academic concept to a tool for political communication. Results from household surveys, especially those of the IBGE, have also been widely reported by the media. It is therefore not surprising that most of the respondents themselves spoke of class. Of the 30 households surveyed, 25 stated that they belonged to the middle class, while only two said they belonged to the rich class and three to the poor class. This means that there is a strong correlation between objective identification of the middle class and subjective perceptions.

\section{Intergenerational mobility}

The first dimension addressed in the interviews is the respondents' assessment of their situation both in relation to their parents' and to their own more or less recent past. Going by the different expressions used by the respondents, three types of judgment were conveyed. In 11 cases out of 30, respondents stated that there had been a marked improvement in their situation compared to earlier periods; a simple improvement was indicated in 17 out of 30 cases; and in two cases the change was considered to have been negative. The "positive change" responses appear to be well correlated with average monthly income per capita. Household heads who considered the change in their situation to have been very positive had higher incomes than the average for the sample (2,982 reais compared to 2,433 reais).

The survey also examined the living conditions of the direct ascendants (only 50\% of whom were still alive at the time of the surveys) of the heads of families surveyed. Out of 58 first generation respondents (two of the household heads interviewed did not know their fathers), it was possible to collect information on place of residence, employment, education and living conditions.

The interview analysis reveals clear trends between generations. Living environments have changed significantly: while rural origins were fairly common in the first generation, migration resulted in the generation surveyed settling in metropolitan urban areas (Rio de Janeiro and Fortaleza). In the field of education, intergenerational changes are no less notable, with, for example, the near disappearance of illiteracy, a reduction in the number of individuals leaving school after only completing the primary level, a significant increase in the number completing the secondary level and, above all, a sharp rise in higher education. The education levels of the respondents (second generation) were as follows: 1 person had no education, 7 had only completed primary education, 9 had gone to secondary school and 13 had gone on to higher education. Regarding employment, lastly, while members of the first generation were primarily involved in agriculture and handicrafts and were therefore somewhat fixed in their type of work and where they did it, the next generation experienced greater job mobility. Of those surveyed, 30 people reported 53 job changes after the first position obtained, representing an average of 1.8 changes per household head interviewed. The survey also reveals that 22 of the 25 active (i.e. not retired) respondents were satisfied with their occupational activity. The ability to work unsupervised, flexible schedules, financial security and the opportunity to improve their professional know-how were the reasons given to justify these positive responses.

Our sample of middle-class households had thus benefited from intergenerational changes in living conditions. However, the current economic crisis is very likely to threaten this upward mobility. In fact, 22 of the 25 respondents who expressed an opinion on the subject deplored the current deterioration of the situation. There was, therefore, full awareness of current changes in relation to employment and wages. 


\section{Socioeconomic behaviour: consumerism sustained by credit}

In line with the literature (SAE, 2012b; Kamakura and Mazzon, 2013), and as already mentioned in relation to the quantitative analysis, Brazilian middle-class households are distinguished by their consumption-oriented behaviour. The prevalence of such behaviour is confirmed by the qualitative survey, most particularly as regards high-technology equipment. Mobile telephony use in Brazil is among the highest in the world, and each of the 30 households in the sample owned at least one mobile phone, often a latest-generation model. Moreover, 27 had Internet access, 23 a computer and 17 a fixed-line telephone at home. Ownership of high-technology equipment would thus appear to be a strong marker of membership of the middle class.

Middle-class consumerism is also reflected in leisure consumption. The households surveyed were questioned about the purpose and nature of their occupations outside working hours. In order of frequency, their answers, which were not limited in number, were as follows: rest (14), sports, leisure, beach (11), culture, cinema, theatre (8), television and Internet (8), reading (4) and visiting family (4). The other 6 activities were very diverse. This suggests a strong demand for recreational activities among Brazilian middle-class families. In particular, 15 of the households interviewed reported travelling, some regularly, others infrequently. Travel for tourism or entertainment purposes or to visit relatives was mentioned by 13 out of 15 households, with the other two mentioning business trips.

A specific feature of Brazil's middle class is the massive use of credit to finance consumer expenditure. De la Torre, Ize and Schmukler (2012) explain that countries with characteristics close to those of Brazil have a level of consumer credit that is only half that prevailing in Brazil. In our survey, 21 of the 30 households surveyed used credit, including seven which had finished paying off a loan and did not have one at the time of the survey. The loans were made by banking institutions in 19 cases and by the companies employing the head of the household in the other 2 cases. Two of the cases involved loans with repayments automatically deducted at source from wages (empréstimos consignados). This method, rare until the 2000s, was greatly expanded during Dilma Rousseff's presidency (2009-2016), characterized by the explosion of credit.

For the 12 households which still had outstanding debt, the interviews identified the level of repayments. These ranged from $7 \%$ to $30 \%$ of total monthly income. The average per capita monthly income of households currently borrowing was 1,938 reais, 500 reais less than the average per capita monthly income of the sample (2,433 reais). In other words, credit was used most at the lower end of the middle class and therefore appears to be a potential source of vulnerability. The explosion of consumer credit over the last 10 years, followed by an abrupt reversal in the country's economic fortunes, has placed many Brazilians in great difficulty. Whereas in 2005 only $18.4 \%$ of Brazilian families were indebted, by September 2016 the figure had reached 58.2\%. A quarter of the indebted families were experiencing difficulties with repayments, and 9.6\% of families were insolvent as of September 2016 (CNC, 2016). Although the households surveyed were not affected by insolvency, it is interesting to note that seven households in the sample reported having stopped using credit cards. There is thus growing caution about debt.

\section{The priorities of the middle classes}

Among the personal and family needs that respondents would most like to see satisfied, health was the most often cited (21 responses), before education (13), security (7), comfort and hobbies (5), etc. When respondents were asked about their expectations for infrastructure in the broadest sense, the health 
sector again came first (cited 11 times), ahead of education (9), security (9), roads (5), transport (5), etc. In other words, it is obvious that the priorities of the Brazilian middle class are primarily in the areas of health, education and security.

We then investigated the likely impacts of a potential improvement in household economic conditions. More specifically, the heads of household surveyed were asked what uses they would make of an increase in income of 50\%. The most frequent responses were: buying an apartment, house or land (13 responses), helping family members (6) and financing education (6). Together with education, the purchase of a car and subscription to private health insurance plans were also included in this list (3 and 2 responses, respectively), confirming the importance of these elements in Brazilian middle-class "culture". Property ownership would clearly be the highest priority in the case of a significant increase in income. This shows interviewees' degree of attachment to housing and land, even though 25 of the 30 households were already property owners. Out of the 25 interviewees who owned their home, 21 considered their local environment to be acceptable or pleasant. For the four interviewees who did not say this, the reason given was the level of violence. Twenty-six of the households interviewed were satisfied with their accommodation; the other four considered their dwelling to be too small. Despite this high level of satisfaction, 10 of the households would have liked to move to a quieter neighbourhood or a larger dwelling, but financial obstacles made it difficult to fulfil this desire.

\section{The middle class and the public sphere}

The relationship to the public authorities can be part of class identity, particularly for the middle class. This is why the following paragraphs address the Brazilian middle class's main expectations in relation to four of the most important dimensions of public action: education, social protection and taxation, public security and corruption.

\section{(a) The education system}

Asked to assess the state of the education system, 17 of the 26 respondents who had some involvement with education expressed critical opinions. These negative judgments related exclusively to public primary and secondary education, and the main criticisms were that the system "leaves much to be desired", "has an inadequate presence in the region", delivered "poor-quality education", had "teachers lacking qualifications and commitment", had "deteriorated significantly", was "unfair", etc. Private establishments were considered to be of good quality and were seen as the only way to escape the mediocrity of the public sector. Although our survey respondents were involved with private education ( 15 had attended at least one private school during their education), it became much more significant with the next generation. When households with children were questioned about their choice of schools, two stated that they had chosen State schools, 12 a mix of State and private schools and 10 exclusively private institutions. ${ }^{3}$ The private sector was therefore present in 22 of the 24 cases surveyed. As already pointed out in the quantitative analysis, this massive recourse to private education has become a strong marker of middle-class membership in Brazil. However, access to private institutions involves costs described by the individuals interviewed as sometimes abusive, thus tending to exclude families with lower incomes. This is one of the hypotheses put forward by Birdsall, Lustig and Meyer (2014): the most vulnerable components of the middle class are likely to have more difficulty using the private sector and thus remain dependent on a poor-quality public education service.

\footnotetext{
3 The combination of public-private education results either from a single child attending both categories or different children from the same family attending different categories of school.
} 
Among the other opinions expressed about the state of the education system, six household heads spoke spontaneously about higher education, judging it difficult to access and expressing the desire to see a greater number of places on bachelor's and master's degree courses. At public universities (especially federal universities and, to a lesser extent, state universities), the number of places is limited and entrance examinations are selective. This is why young people from private secondary institutions have the greatest chances of obtaining a high-quality public higher education. The strictly limited intake at public universities has the effect of driving large numbers of students into private universities, which thus represent a lucrative market, but whose official evaluations show them to be of lower quality.

\section{(b) Social protection and taxation}

As regards social security (sickness, occupational injury, old-age pensions), almost all the households surveyed (29 out of 30 ) were covered by the basic schemes, namely the general social security scheme and the public sector employees' scheme, with one household covered by the special scheme for military personnel). These basic schemes were severely criticized (27/30) by the households surveyed. Respondents' criticisms included: poor use of contributions, mismanagement of funds, delays in the payment of benefits and even embezzlement. In addition to these basic schemes, there are private health plans run by insurance companies for which premiums are particularly expensive. Such plans entitle subscribers to more rapid medical consultations and hospitalizations than the public health system, depending on the size of their contributions. Undoubtedly, subscription to these private health schemes is in many respects a distinctive feature of the Brazilian middle class, since 19 households in our sample had this type of insurance. However, a household's financial capacity is decisive in determining access to such private health insurance. Nine of the 11 households that did not have a private plan had a monthly per capita income of below 2,000 reais, significantly lower than the average income in the sample (2,433 reais). Once again, this tends to confirm the hypothesis of Birdsall, Lustig and Meyer (2014) that the more insecure members of the middle-income group cannot afford private insurance and therefore remain more dependent on lower-quality public health services.

Linked to these redistributive issues is taxation, considered too heavy by 26 households, which thus confirmed the essence of the criticisms regularly raised in Brazil. These are expressed in various ways but can be summarized as follows: a lack of "return" benefiting the population, mismanagement of public funds, misuse of taxes, poor public services and the absurdity of some taxes levied even on matches and books. Overall, since it mainly bears on goods and services, the Brazilian tax system places excessive pressure on poor and intermediate social groups (Silveira and others, 2011). In 2013, of the total tax collected by the three levels of government, $51.3 \%$ was levied on goods and services, $18.1 \%$ on income and $3.9 \%$ on property. This tends to confirm the hypothesis of Birdsall, Lustig and Meyer (2014) that high indirect taxation contributes to the continuing vulnerability of part of the middle class. ${ }^{4}$

\section{(c) Public security}

The Atlas of Violence recorded 59,627 homicides for the year 2014, an increase of nearly 22\% on 2003 (IPEA/FBSP, 2016). The rate of 29.1 homicides per 100,000 inhabitants this works out at is the highest in Brazil's history and places it among the 10 most dangerous countries in the world. Besides the human tragedy, the economic cost is considerable. A study by the Inter-American Development Bank (IDB) estimates the cost of crime at nearly $4 \%$ of Brazil's GDP. What did households in the sample feel about these worrying questions? When asked about their assessment of public security in the area

\footnotetext{
4 Afonso and Castro (2012) refer to a recent study from the University of São Paulo showing that 49\% of the income of households in the bottom income decile is taken by the tax authorities, compared to just $26 \%$ of the income of households in the top income decile. Tax deductions tend mechanically to increase the benefits of rich taxpayers.
} 
where they lived, the respondents' opinion was almost unanimously negative. Of the 30 respondents, 28 felt unsafe: "We walk down the street constantly fearing attack", "There's nothing we can do about the criminals", "Crime is lurking everywhere", "Violence is taking over streets and neighbourhoods", etc. Furthermore, 28 respondents said that they themselves or members of their family had already been victims of violence, mostly attacks and robberies, plus one case of kidnapping for ransom and two cases of homicide. The recriminations focused on the failings of the public security forces and included "a very sluggish police force which leaves much to be desired", "inefficient", "deficient", "disorganized and bewildered", "in crisis", "non-existent", "contributing to the chaos", etc.

\section{(d) Politics and corruption}

Our survey was carried out in a national political context tarnished by multiple corruption scandals involving a number of politicians at all three levels of government (federal, state and municipal), including the two most recent former presidents, Lula da Silva and Dilma Rousseff, as well as business leaders. While Brazilians' opinion of politics has worsened with the current proliferation of "cases", they have had a very negative image of their representatives and authorities for a long time, regardless of which government has been in power. Respondents spoke freely and spontaneously, using their own words and expressions. The adjectives frequently associated with politics defined it as "dreadful", "corrupt", "awful", "dishonest", "filthy", "wrong", "getting worse by the day", "the exact opposite" of what it should be. Several respondents said they were "saddened" and "disgusted". They criticized politicians for "forgetting their promises", "not being serious" and "diverting public funds".

An important dimension of politics and governance is corruption. The Corruption Perceptions Index of Transparency International, a non-governmental organization, ranked Brazil seventy-ninth out of 176 countries for the year 2016. Moreover, $78 \%$ of Brazilian people think that corruption is endemic and increasing in their country (Transparency International, 2017). The existence of corruption in Brazil was affirmed by all 30 households. Among them, 14 said that it was ubiquitous in all or most sectors (the most often cited were education, health, social security and transport), but 16 households of the 30 said that it was concentrated in the political sphere or, more precisely, within the political parties, Congress, the executive and the legislature, with several citing the capital Brasilia as the focal point of these practices. The reality of small-scale, everyday corruption in administrative formalities was recognized by 23 of the 30 households, with 13 stating they had been victims of it. Lastly, several respondents said that the general population contributed to the frequency of such practices, as minor everyday lawbreaking (o jeitinho) ${ }^{5}$ provided a climate conducive to the development of illicit practices.

\section{Conclusion}

Following this in-depth analysis of Brazil's growing middle class and its relationship to public policies, we can identify a number of stylized facts.

We estimate that the middle-income class accounted for over $61.4 \%$ of the population in 2014 , a level consistent with previous estimates. The significant increase in the size of this middle-income group since the early 2000 s is also confirmed. Our study also shows that the middle-income class in Brazil is particularly heterogeneous in terms of education, occupation and employment status, since seven distinct groups were identified within that class. Our typology tends to emphasize the existence of a degree of bipolarization within the Brazilian middle class, with a limited upper middle class holding

\footnotetext{
5 The term jeitinho is commonly used in Brazil to describe small, everyday methods of getting around the law such as bribes, tips, exchanges of services, etc.
} 
stable and highly skilled jobs (especially in the public sector) and a large, vulnerable middle class with lower income and education levels and more unstable, lower-quality jobs. Although this latter category is often depicted as the "new middle class" in Brazil, it is clear that people in this group have not attained to the stability and living conditions traditionally associated with membership of the middle class. Moreover, they are directly threatened by the collapse of the job market and the problems of overindebtedness linked to the current economic crisis.

The Brazilian middle class is also characterized by its consumption-oriented behaviour. The purchase of durable goods, housing and leisure appears to be a strong marker of middle-class membership. This consumerism has been largely fuelled by easier access to credit. In terms of its expectations and aspirations, Brazil's middle class cites health, education, public security and housing as priorities. The middle class judges the quality of public infrastructure and services very harshly, all the more so because it is aware that the Brazilian tax system is pro-rich. It is true that the upper middle class is distinguished by its ability to circumvent the failings of the public sector by using the private sector, particularly in education and health. However, the most vulnerable families in the middle class remain highly dependent on poor-quality public services. Lastly, like the rest of the Brazilian population, the middle class expresses its repudiation of the political system at all levels of power, stressing its inability to work for the general interest. In particular, the country's endemic corruption is severely criticized.

Although this study provides interesting insights into the size, composition, behaviours and expectations of the Brazilian middle class, further research is still needed. Without being exhaustive, three lines of research could be envisaged.

First, the vulnerability of the Brazilian middle class needs to be better analysed, particularly by focusing on the distinction between objective and subjective vulnerability. Our method of identifying the Brazilian middle class takes into account such important dimensions of vulnerability as income and labour market status. Nonetheless, in line with Stampini and others (2016), we suggest that our objective identification of the middle class could be complemented by a measure of objective vulnerability based on the probability of falling into poverty. As for subjective vulnerability, our qualitative survey of members of the middle class provides some evidence for perceived difficulties regarding education, health and credit in the current context of economic crisis. Further research could be conducted to arrive at a better understanding of how the objective and subjective dimensions of vulnerability interact. It may be argued that there is a potential gap between the two dimensions of vulnerability, with the subjective fear of downgrading being greater than objective vulnerability.

Second, the heterogeneity of the Brazilian middle class has potentially important implications for social cohesion that should be addressed. As already explained, the middle class is bipolarized, with a large and vulnerable component that remains dependent on poor-quality public services and an upper component that can afford private mechanisms and thus avoid depending on those public services. In many respects, this well-off middle class shares characteristics and behaviours with the richest class. This could indicate that the culture of privilege, historically rooted in Brazilian society, spills over into the upper middle class. Moreover, increasing recourse to market mechanisms obviously challenges the idea of a social State that could have emerged with the social policies implemented during the past decade.

Third, the heterogeneity of the Brazilian middle class also has implications for political and civic commitment. Examining the capacity of this fragmented middle class for collective action is a particularly important area for future research. Members of the Brazilian middle class, especially the most vulnerable, have recently proven their ability to mobilize and demonstrate, as they did during mass gatherings from March to June 2013 (Fauré, 2014). Although the initial message was their opposition to the tremendous expenditure associated with the 2014 FIFA World Cup and the 2016 Rio Olympics, the protests then broadened out greatly to include the denunciation of corruption, public insecurity and failures in public services. These expressions of discontent can be analysed as a new wave of 
citizen-based activism, strongly supported by the large-scale use of social networks on the Internet. However, this activism has been primarily driven by new entrants into the middle class who remain highly vulnerable (Biekart, 2015). Although the different components of the Brazilian middle class share common expectations, the fragmentation of that class might limit its capacity to mobilize collectively over shared demands. More specifically, the upper middle class's ability to afford market mechanisms means it is probably less interested than the rest of the group in demanding improved public services. Examining the extent to which the weak cohesion of the Brazilian middle class may obstruct policies that would favour its most vulnerable components would be a promising avenue for future research.

\section{Bibliography}

Afonso, J. R. R. and K. P. Castro (2012), "Tributação: insuficiente reformar, necessário novo sistema”, Controle, vol. 10, No. 2, Fortaleza, Court of Accounts of Ceará State.

AsDB (Asian Development Bank) (2010), "The rise of Asia's middle class", Key Indicators for Asia and the Pacific 2010, Metro Manila.

Banerjee, A. and E. Duflo (2008), "What is middle class about the middle classes around the world?", Journal of Economic Perspectives, vol. 22, No. 2, Nashville, American Economic Association.

Biekart, K. (2015), "The choice of the new Latin American middle classes: sharing or self-caring", The European Journal of Development Research, vol. 27, No. 2, Berlin, Springer.

Birdsall, N. (2010), "The (indispensable) middle class in developing countries", Equity and Growth in a Globalizing World, R. Kanbur and M. Spence (eds.), Washington, D.C., World Bank.

Birdsall, N., C. Graham and S. Pettinato (2000), "Stuck in the tunnel: is globalization muddling the middle class?", Brookings Institution Working Paper, No. 14, Washington, D.C., Center on Social and Economic Dynamics.

Birdsall, N., N. Lustig and C. J. Meyer (2014), "The strugglers: the new poor in Latin America?", World Development, vol. 60, Amsterdam, Elsevier.

Bonnefond, C., M. Clément and F. Combarnous (2015), "In search of the elusive Chinese urban middle class: an exploratory analysis", Post-Communist Economies, vol. 27, No. 1, Abingdon, Taylor \& Francis.

Castellani, F. and G. Parent (2011), "Being 'middle class' in Latin America", OECD Development Centre Working Paper, No. 305, Paris, OECD Publishing.

CNC (National Confederation of Commerce of Goods, Services and Tourism) (2016), Pesquisa nacional de endividamento e inadimplência do consumidor, Brasilia.

De la Torre, A., A. Ize and S. L. Schmukler (2012), Financial Development in Latin America and the Carribean: The Road Ahead, Washington, D.C., World Bank.

Easterly, W. (2001), "The middle class consensus and economic development", Journal of Economic Growth, vol. 6, No. 4, Berlin, Springer.

Fauré, Y.-A. (2014), "Bonheur privé, carences publiques : retour sur la fronde sociale de mars-juin 2013 au Brésil", Problèmes d'Amérique Latine, No. 93, Paris, ESKA.

Ferreira, F. H. G. and others (2013), Economic Mobility and the Rise of the Latin American Middle Class, Washington, D.C., World Bank.

Franco, R., M. Hopenhayn and A. León (2011), "The growing and changing middle class in Latin America: an update", CEPAL Review, No. 103 (LC/G.2487-P), Santiago, Economic Commission for Latin America and the Caribbean (ECLAC).

IPEA/FBSP (Institute of Applied Economic Research/Brazilian Forum of Public Security) (2016), "Atlas da violência 2016", Nota Técnica, No. 17, Brasilia.

Kamakura, W. A. and J. A. Mazzon (2013), Estratificação socioeconômica e consumo no Brasil, São Paulo, Blucher.

Kharas, H. (2010), "The emerging middle class in developing countries", OECD Development Centre Working Paper, No. 285, Paris, OECD Publishing.

Milanovic, B. and S. Yitzhaki (2002), "Decomposing the world income distribution: does the world have a middle class?", Review of Income and Wealth, vol. 48, No. 2, Hoboken, Wiley.

Neri, M. C. (coord.) (2012), De volta ao país do futuro: crise européia, projeções e a nova classe média, Rio de Janeiro, Getúlio Vargas Foundation (FGV).

Neri, M. C. and L. C. C. de Melo (coords.) (2008), Miséria e a nova classe média na década da igualdade, Rio de Janeiro, Getúlio Vargas Foundation (FGV). 
Pochmann, M. (2012), Nova classe média?: O trabalho na base da pirâmide social brasileira, São Paulo, Boitempo. Ravallion, M. (2010), "The developing world's bulging (but vulnerable) middle class", World Development, vol. 38, No. 4, Amsterdam, Elsevier.

SAE (Strategic Affairs Secretariat) (2012a), Commissão para definição da classe média no Brasil, Brasilia. (2012b), Vozes da classe média. Caderno 1, Brasilia.

Scalon C. and A. Salata (2012), "Uma nova classe média no Brasil da última década?: O debate a partir da perspectiva sociológica", Sociedade e Estado, vol. 27, No. 2, Brasilia, University of Brasilia.

Silveira, F. G. and others (2011), "Equidade fiscal no Brasil: impactos distributivos da tributação e do gasto social”, Comunicados do IPEA, No. 92, Brasilia, Institute of Applied Economic Research (IPEA).

Song, J. and others (2016), "Social stratification and mobility among Chinese middle class households: an empirical investigation", International Business Review, vol. 25, No. 3, Amsterdam, Elsevier.

Stampini, M. and others (2016), "Poverty, vulnerability, and the middle class in Latin America", Latin American Economic Review, vol. 25, No. 4, Berlin, Srpinger.

Transparency International (2017), People and Corruption: Latin America and the Carribean. Global Corruption Barometer, Berlin.

Xavier Sobrinho, G. de F. (2011), “A ‘classe C' e sua alardeada ascensão: nova? classe? média?”, Indicadores Econômicos FEE, vol. 38, No. 4, Porto Alegre, Foundation of Economics and Statistics Siegfried Emanuel Heuser. 